\title{
Mechanical properties and crystallinity of linier low density polyethylene based biocomposite film
}

\author{
Dodi Irwanto*, Bidhari Pidhatika, Dwi Wahini Nurhajati, Syaiful Harjanto \\ Center for Leather, Rubber, and Plastics, Jl. Sokonandi No. 9, Yogyakarta 55166, Indonesia. \\ *Corresponding author. Tel.: +62 274 512929; Fax.: +62 274563655 \\ E-mail: dodiirwanto@yahoo.co.id
}

Submitted: 1 October $2019 \quad$ Revised: 9 December $2019 \quad$ Accepted: 12 December 2019

\begin{abstract}
Cassava starch filled linear low-density polyethylene (LLDPE) films are made in order to make plastics which environmentally friendly. The use of compatibilizer ethylene - acrylic ester - maleic anhydride polymerized is needed to obtain a compatible mixture of starch which is hydrophilic and LLDPE which is hydrophobic. In this study LLDPE films obtained were tested for tensile strength and elongation before and after accelerated aging and density. Melt flow index (MFI) of the film was also measured to determine the rheological properties. Crystallinity has been done by an X-Ray diffraction. The results showed that the addition of thermoplastic starch tended to reduce the tensile strength, elongation, and MFI values but increase the density of LLDPE films. The aging process at a temperature of $70{ }^{\circ} \mathrm{C} \pm 2{ }^{\circ} \mathrm{C}$ for 168 hours \pm 2 hours tends to increase the tensile strength but decrease the extension of the break.
\end{abstract}

Keywords: biocomposite film, cassava starch, crystallinity, LLDPE, mechanical properties

\section{INTRODUCTION}

The development of biodegradable plastics from natural polymers is emerging due to problems associated with non-biodegradable plastics wastes all over the world. To this end, one of prospective materials that have been widely investigated is cassava starch. Although prospective in terms of biodegradability, low-cost, and abundant availability, cassava starch is brittle and difficult to process. Addition of plasticizer is, in general, needed to reduce its brittleness. One of common plasticizers is a mixture of water and glycerol (Adamu et al., 2017; Lutfi et al., 2017; Mendes et al., 2016). Cassava starch can be co-compounded with synthetic polymer and enhance the (partial) biodegradability of the final compound. Cocompounding between starch and polyolefin has been reported in literature. Wan et al. (2014) and Obasi and Igwe (2014) reported the development starch/polypropylenebased plastics. Tanetrungroj and Prachayawarakorn (2015) and Nguyen et al. (2016) reported the co-compounding between starch and low-density polyethylene. In general, the starch composition in the co-compound is less than $50 \%$. Another prospective polyolefin for the development of biodegradable plastics is linier low-density polyethylene (LLDPE). LLDPE is a synthetic polymer that is generally used for packaging due to its flexibility and elasticity, allowing the preparation of thinner plastics film compared to other polyolefins. LLDPE is chemical resistant, transparent, and inexpensive, however, it is nonbiodegradable. Co-compounding between LLDPE and cassava starch results in biodegradable plastics composite
(Nguyen et al., 2016). Due to polarity difference, LLDPE and starch are not miscible. Maleic anhydride grafted polyethylene (PE-g-MA) has been widely used as compatibilizer for starch and polyethylene co-compounds (Samper et al., 2015; Sabetzadeh et al., 2015; Oragwu, 2016).

In the present work, LLDPE is co-compounded with cassava starch, using ethylene acrylic ester maleic anhydride terpolymer as compatibilizer. The starch was hydrolyzed to break the branched amylopectins that are responsible for the inflexibility and brittleness of the starch-based products. We have previously reported the biodegradability of identical co-compound, in which the product was exposed to microorganisms-containing media at ambient temperature (Nurhajati et al., 2018). Different from the previous publication, here we report the physical properties, i.e. density, melt flow index, and crystallinity, of the co-compounds as a function of starch content, as well as the stability of the co-compound at elevated temperature $\left(70^{\circ} \mathrm{C}\right)$.

\section{MATERIALS AND METHOD \\ Materials}

Identical materials as reported in our previous publication (Nurhajati et al., 2019) were used. LLDPE resin Asrene UF 1810T (extrusion grade, density 0.921 $\mathrm{g} / \mathrm{cm}^{3}$, and melt index $\left.1 \mathrm{~g} / 10 \mathrm{~min}\left(190{ }^{\circ} \mathrm{C} / 2.16 \mathrm{~kg}\right)\right)$ was purchased from PT Chandra Asri. Orang Tani ${ }^{\circledR}$ cassava starch powder was used for preparing thermoplastic starch (TPS) formulations. Compatibilizer Lotrader 
4210 and antioksidan Songnox 1010 were purchased from PT Bunga Permata and PT. Intera Lestari Polimer, respectively. Aquadest, stearic acid, and glycerol were purchased from Bratachem.

\section{Experimental equipment}

Internal mixer Haake Rheomix was used for cocompounding process, hydraulic press was used for preparing plastics film, Universal Testing Machine (UTM) Tinius Olsen-H25K was used for the determination of tensile strength before and after stability test at elevated temperature. Densimeter EW-200SG Mirage, melt flow indexer (MFI) Tinius Olsen-MP 1200, and X-ray diffraction (XRD) Rigaku miniflex 600 were used for the determination of density, melt flow index, and crystallinity of the co-compound, respectively.

\section{Methods}

Prior to mixing with LLDPE, a homogenized mixture of $10 \%$ water, $20 \%$ glycerol, and $70 \%$ starch was prepared. The starch was then co-compounded with LLDPE with varying composition of $30,40,50,60,70$ phr. In addition, 5 phr Lotader 4210 as a compatibilizer was added. The starch/LLDPE film was then prepared using hydraulic press at $150{ }^{\circ} \mathrm{C}$ and $150 \mathrm{~kg} / \mathrm{cm}^{2}$. The mixing and co-compounding process was performed in an internal mixer (Haake Rheomix) at $130^{\circ} \mathrm{C}$ and $40 \mathrm{rpm}$ for 15 min (Nurhajati et al., 2019).

\section{Physical properties testing}

Physical properties that include density (ISO 11831:2012, method A), melt flow index (ASTM D1238, at $2.16 \mathrm{~kg}$ and $190^{\circ} \mathrm{C}$ ), and crystallinity of the resulting starch/LLDPE film were then measured. The crystallinity was measured using X-ray diffractometer, at $2 \theta=0-70^{\circ}$, $40 \mathrm{kV}, 20 \mathrm{~mA}$, and degree per minute. Crystallinity degree (Xc) was determined according to:

$$
X c=\frac{\text { Crystalline area } x 100 \%}{\text { Total area (crystalline }+ \text { amorphous) }}
$$

Stability of the film upon exposure to high temperature $\left(70{ }^{\circ} \mathrm{C} \pm 2{ }^{\circ} \mathrm{C}\right.$ ) was performed in an oven for $168 \pm 2 \mathrm{~h}$. The tensile strength and elongation at break of the film before

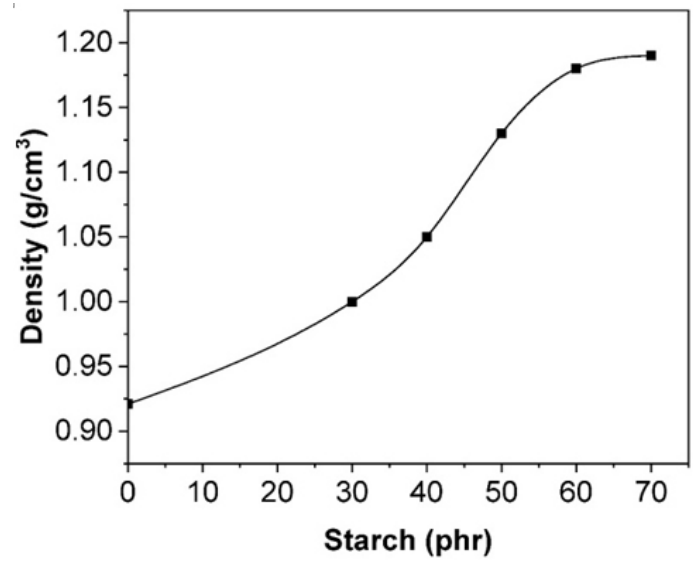

(a) and after exposure to the aging treatment were measured according to SNI ISO 11193.2:2010 to determine the film stability. Tensile strength and elongation at break measurements refers to ASTM D 882.

\section{RESULTS AND DISCUSSION}

Starch/LLDPE Film Density, Melt Flow Index, and Crystallinity

Figure 1 shows the density of starch/LLDPE film and melt flow index as a function of starch content. It is shown that the film density increases with increasing starch content in the film. This result is expected, because starch $\left(1.5 \mathrm{~g} / \mathrm{cm}^{3}\right)$ possesses higher density than LLPDE $\left(0.921 \mathrm{~g} / \mathrm{cm}^{3}\right)$. Similar results were reported by Kormin et al. (2017) and Nurhajati et al. (2019).

In contrast to the density profile, figure 1(b) and table 1 shows a decrease in MFI and degrees of crystallinity as starch content increases. MFI determines the flowability of a polymer material. In this study, MFI test was performed at $190^{\circ} \mathrm{C}$ and $2.16 \mathrm{~kg}$. Addition of 30 and $70 \mathrm{phr}$ starch decreases the film's MFI by a factor of $26 \%$ and $93 \%$, respectively. In general, higher density leads to higher viscosity and lower flowability, as shown in figure 1(a) and (b). Similar results have been reported by Oduola and Akpeji (2015) on cassava starch/polypropylene (PP), Kormin et al. (2017) on starch/LDPE, Atli et al. (2018) on sawdust/Bioplast GS 2189, and Zhang (2018) on polylactic acid (PLA)/polyolefin elastomer (POE)/modified starch mixture.

The resulting diffractogram pattern is diffraction peaks with varying intensities. Each peak has a different high intensity. Polymers can contain crystalline regions mixed with amorphous regions. X-ray diffractograms of crystalline polymers produce sharp peaks, whereas amorphous polymers tend to produce widening peaks. In general, the polymeric material is semicrystalline, which means it has both an amorphous and crystalline part. The XRD test results related to peaks at 2-theta and the intensity for LLDPE film results are presented in Figure 2.

In Figure 2, LLDPE films without starch appear 2 dominant peaks at 2 -theta $=21.76^{\circ}$ and $24.14^{\circ}$ and a peak that widens at $2 \theta=19.46^{\circ}$. This is similar to Kim and Lee

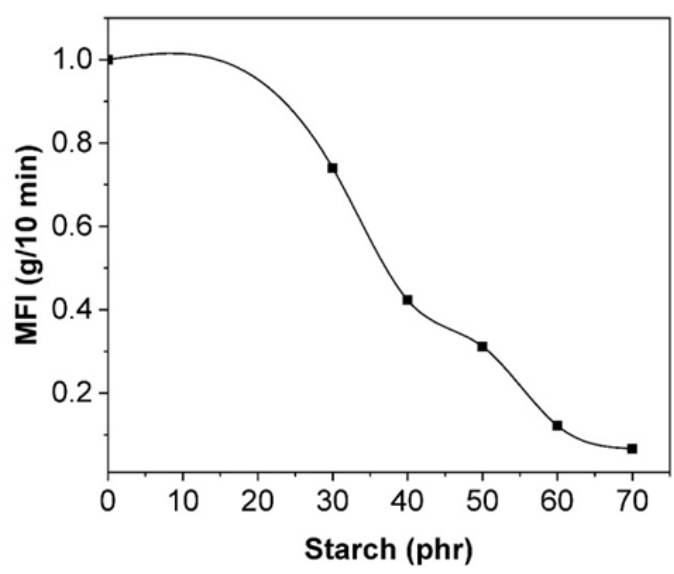

(b)

Figure 1. Starch/LLDPE film density (a) and melt flow index (b) as a function of starch content. 
(2017) $\left(21.6^{\circ}\right.$ and 24.0), and Wang et al. (2019) (20.94 and $\left.23^{\circ}\right)$. Starch containing plasticizers have 5 main peaks at 2-theta $=15.22^{\circ}, 17.2^{\circ}, 18^{\circ}, 20.4^{\circ}$, and $23.1^{\circ}$. This result is similar to Lomelí et al. (2014) $\left(15.2^{\circ}, 17.2^{\circ}\right.$, $18.1^{\circ}, 20.1^{\circ}$ and $\left.23.1^{\circ}\right)$ and Ajiya et al. (2018) $\left(15^{\circ}, 17^{\circ}\right.$ $\left.19^{\circ}, 24^{\circ}\right)$.

LLDPE film with $30 \mathrm{phr}$ starch content has two main peaks at 2-theta $=21.8^{\circ}$ and $24.08^{\circ}$. The addition of tapioca starch $50 \mathrm{phr}$ shows a mixed pattern with two main peaks at 2-theta $=21.74^{\circ}$, and $23.82^{\circ}$ (Figure 2d). The addition of tapioca starch $70 \mathrm{phr}$ shows a mixed pattern with two main peaks at 2-theta $=21.96^{\circ}$ and $24.44^{\circ}$. The addition of starch causes a decrease in intensity. Figure 2 shows that the LLDPE component causes the main peak intensity in the diffractogram, even though the LLDPE component is incorporated into the composite less than starch (Figure 2e)). This is in line with the results of research by Tanetrungroj and Prachayawarakorn (2015).

\section{Tensile Strength and Elongation at Break}

Mechanical stability upon exposure to elevated temperature (i.e. accelerated aging) is one of quality standards for plastics-based glove products. In this study, the tensile strength and elongation at break were measured at elevated temperature $70 \pm 2{ }^{\circ} \mathrm{C}$ for $168 \pm 2 \mathrm{~h}$. Figure 3 shows the tensile strength and elongation at break as function of starch content. It is seen from figure 3(a) that tensile strength (TS) before thermal aging decreases with increasing starch content in the composite film. After thermal aging, TS decreases with increasing starch content up to $70 \mathrm{phr}$. Further increase in starch content increases the TS. On the other hand, elongation at break (EB) data in figure 3(b) shows decrease of EB values with increasing starch content, both before and after thermal aging. After $40 \mathrm{phr}$, however, the EB value plateaus for the samples after aging.

The decreasing trend of TS as a function of starch content in figure 3(a) indicates low interfacial adhesion between the LLDPE matrix with the starch molecules. Agglomerates of ungelatinized starch molecules that are not fully covered by the LLDPE matrix can also worsen the interfacial adhesion, leading to low mechanical properties of the composite. The weak interfacial adhesion also contributes to the decrease in EB values, as observed in figure $3(\mathrm{~b})$. It is also known that brittleness is one of the main drawbacks in starch-containing materials. In principle, starch is polysaccharide consisting of amylose (linier chains) and amylopectin (branched chains).

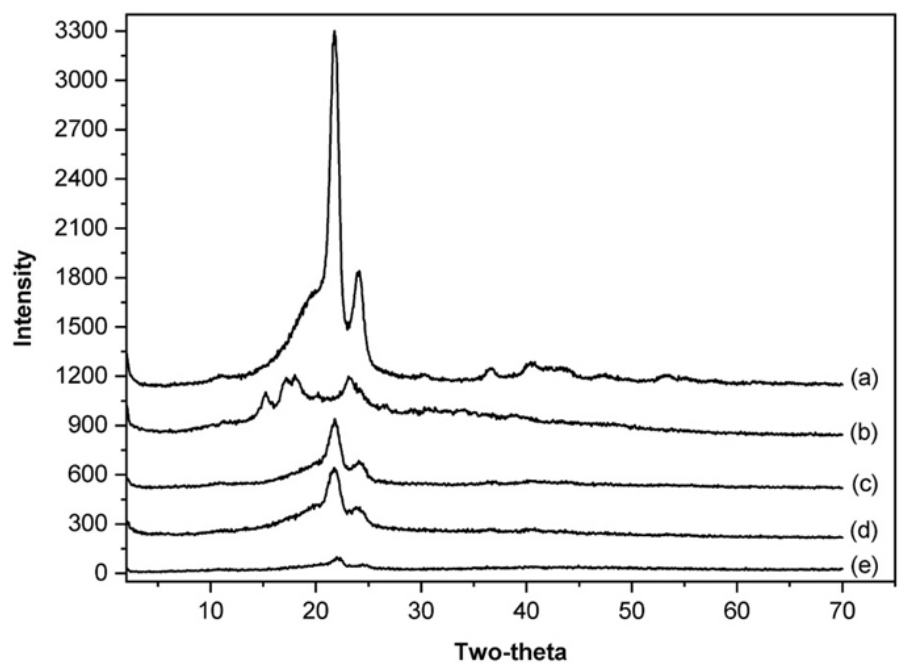

Figure 2. XRD diffractogram from LLDPE film (a), Starch containing additives (b), LLDPE films on various amounts of starch (c. $30 \mathrm{phr}, \mathrm{d} .50 \mathrm{phr}$, e. $70 \mathrm{phr}$ ).

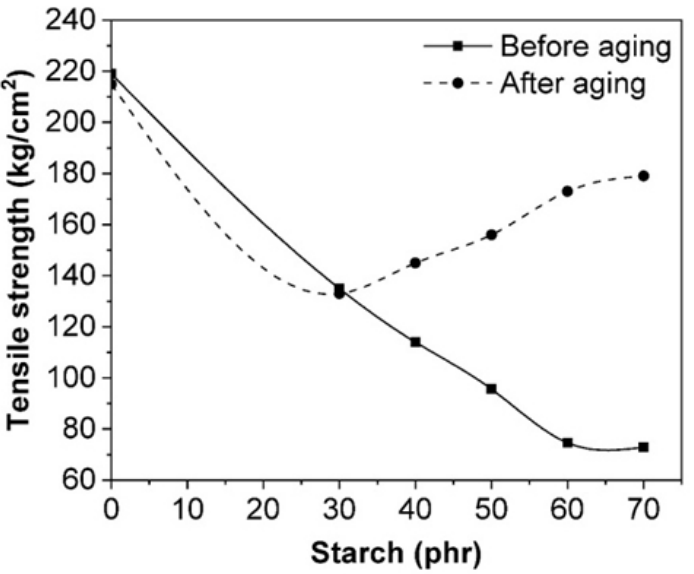

(a)

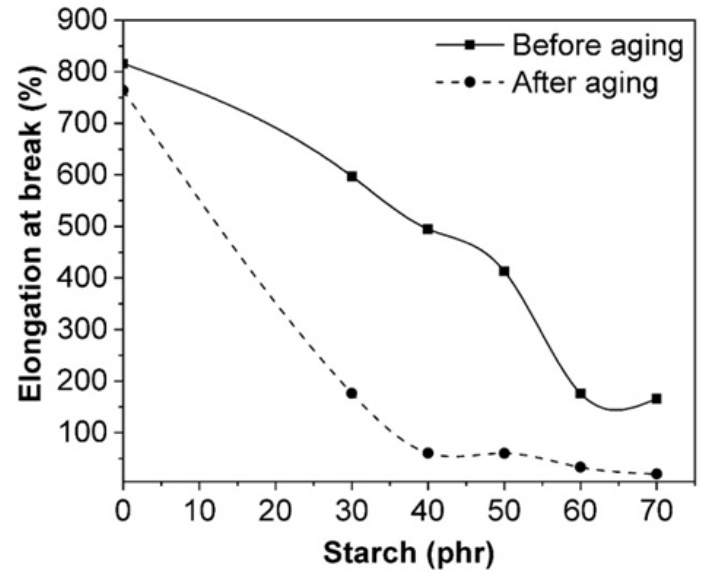

(b)

Figure 3. The effect of starch content to (a) tensile strength and (b) elongation at break of LLDPE/starch film. 
Table 1. Degrees of crystallinity.

\begin{tabular}{|c|c|}
\hline Sample & Crystallinity (\%) \\
\hline LLDPE & 0.53 \\
\hline Starch containing additives & 39.19 \\
\hline LLDPE films on $30 \%$ of starch & 30.21 \\
\hline LLDPE films on $50 \%$ of starch & 27.12 \\
\hline LLDPE films on $70 \%$ of starch & 13.02 \\
\hline
\end{tabular}

The reason for brittleness of starch has been explained elsewhere. Similar results were reported by Yamak (2016) and Sanyang et al. (2015).

Thermal aging of the starch/LLDPE film at $70 \pm 2{ }^{\circ} \mathrm{C}$ for $168 \pm 2 \mathrm{~h}$ changes the TS and EB trends as described in the previous paragraph. Exposure to high temperature might modify the water content, molecular arrangement, and gelatinization state of the starch molecules inside the film, leading to more crosslinking and stronger interfacial adhesion between the polymer chains. Both factors lead to higher TS and lower EB values, as observed in figure 3(b). Similar results were reported by Pg Adnan and Arshad (2017). Based on the standard and the experimental results shown in figure 3, starch/LLDPE film with starch content $\leq 20 \mathrm{phr}$ is the most suitable material for the particular application.

\section{CONCLUSION}

The addition of thermoplastic starch tended to reduce the tensile strength, elongation, and MFI values but increase the density of LLDPE films. The aging process at a temperature of $70^{\circ} \mathrm{C} \pm 2^{\circ} \mathrm{C}$ for 168 hours \pm 2 hours tends to increase the tensile strength but decrease the extension of the break.

\section{ACKNOWLEDGEMENT}

The authors acknowledge the Center for Leather, Rubber and Plastics, and Metal Industries Development Center.

\section{REFERENCES}

Adamu, A. D., Jikan, S. S., Talip, B. H. A., Badarulzaman, N. A., \& Yahya, S. (2017). Effect of glycerol on the properties of tapioca starch film. Materials Science Forum, 888, 239-243. https://doi.org/10.4028/www.scientific.net/MSF.888.239

Ajiya, D. A., Jikan, S. S. B., Talip, B. A., Matias-Peralta, H. M., Badarulzaman. N. A., \& Yahya, S. (2018). Physical properties of edible films based on tapioca starch as affected by the glycerol concentration. International Journal of Current Science, Engineering \& Technology, 1(S1), 410415. https://doi.org/10.30967/ijcrset.1.S1.2018.410-415

ASTM (American Society for Testing and Materials). (2018). ASTM D882: Standard test method for tensile properties of thin plastic sheeting. Pennsylvania, USA: ASTM.

Atli, A., Candelier, K., \& Alteyrac, J. (2018). Mechanical, thermal and biodegradable properties of bioplast-spruce green wood polymer composites. International Journal of Chemical, Materials and Biomolecular Sciences, 11(5), 226-238. https://doi. org/10.5281/zenodo. 1317160

Kim, J. W., \& Lee, J. S. (2017). Effect of heat drawing process on mechanical properties of dry-jet wet spun fiber of linear low density polyethylene/carbon nanotube composites. International Journal of Polymer Science, 2017, 1-9. https://doi.org/10.1155/2017/6197348

Kormin, S., Kormin, F., Beg, M. D. H., \& Piah, M. B. M. (2017). Physical and mechanical properties of LDPE incorporated with different starch sources. IOP Conference Series: Materials Science and Engineering, 226, 012157. https:// doi.org/10.1088/1757-899X/226/1/012157

Mendes, J. F., Paschoalin R. T., Carmona V. B., Neto, A. R. S., Marques, A. C. P., Marconcini J. M., Mattoso, L. H. C., Medeiros, E. S., \& Oliveira, J. E. (2016). Biodegradable polymer blends based on corn starch and thermoplastic chitosan processed by extrusion. Carbohydrate Polymers, 137, 452-458. $\quad$ https://doi.org/10.1016/j. carbpol.2015.10.093

Lomelí-Ramirez, M. G., Kestur, S. G., Manríquez-González, R., Iwakiri, S., de Muniz, G. B., \& Flores-Sahagun, T. S. (2014). Bio-composites of cassava starch-green coconut fiber: Part II - Structure and properties. Carbohydrate Polymers, 102, 576-583. https://doi.org/10.1016/j.carbpol.2013.11.020

Lutfi, M., Sumarlan, S. H., Susilo, B., Wignyanto, Zenata, R., \& Perdana, L. P. R. (2017). The glycerol effect on mechanical behaviour of biodegradable plastic from the Walur (Amorphophallus paenifolius var. sylvestris). Nature Environment and Pollution Technology, 16(4), 1121-1124.

Nguyen, D. M., Do, T. V. V., Grillet, A., Thuc, H. H., \& Thuc, C. N. H. (2016). Biodegradability of polymer film based on low density polyethylene and cassava starch. International Biodeterioration \& Biodegradation, 115, 257-265, https:// doi.org/10.1016/j.ibiod.2016.09.004

Nurhajati, D. W., Pidhatika, B., \& Harjanto, S. (2019). Biodegradable plastics from linier low-density polyethylene and polysaccharide: The influence of polysaccharide and acetic acid. Majalah Kulit, Karet, dan Plastik, 35(1), 33-40. http://doi.org/10.20543/mkkp.v35i1.4874

Nurhajati, D. W., Indrajati I. N., Mayasari, H. E., \& Sholeh, M. (2018). Pengaruh penambahan pati tapioka terhadap sifat mekanis dan struktur komposit high density polyethylene. Majalah Kulit, Karet, dan Plastik, 34(2), 77-84. https://doi. org/10.20543/mkkp.v34i2.4138

Obasi, H. C., \& Igwe, I. O. (2014). Effects of native cassava starch and compatibilizer on biodegradable and tensile properties of polypropylene. American Journal of Engineering Research, 3(2), 96-104.

Oduola, M. K., \& Akpeji, P. O. (2015). Effect of starch on the mechanical and rheological properties of polypropylene. American Journal of Chemical Engineering, 3(2-1), 1-8. https://doi.org/10.11648/j.ajche.s.2015030201.11

Oragwu, I. P. (2016). Investigations on the corn-starch modified low density polyethylene blends. Matter: International Journal of Science and Technology, 2(1), 1-11. https://doi. org/10.20319/mijst.2016.21.0111

Pg Adnan, D. N., \& Arshad, S. E. (2017). Effect of thermal treatment on mechanical properties rice husk ash filled tapioca starch composite. Transactions on Science and 
Technology, 4(3-2), 286-291.

Sabetzadeh, M., Bagheri, R., \& Masoomi, M. (2015). Study on ternary low density polyethylene/linear low density polyethylene/thermoplastic starch blend films. Carbohydrate Polymers, 119, 126-133. https://doi. org/10.1016/j.carbpol.2014.11.038

Samper-Madrigal, M. D., Fenollar, O., Dominici, F., Balart, R., \& Kenny, J. M. (2015). The effect of sepiolite on the compatibilization of polyethylene-thermoplastic starch blends for environmentally friendly films. Journal of Materials Science, 50, 863-872. https://doi.org/10.1007/ s10853-014-8647-8

Sanyang, M. L., Sapuan, S. M., Jawaid, M., Ishak, M. R., \& Sahari, J. (2015). Effect of plasticizer type and concentration on physical properties of biodegradable films based on sugar palm (arenga pinnata) starch for food packaging. Journal of Food Science and Technology, 53, 326-336, https://doi. org/10.1007/s13197-015-2009-7

BSN (Badan Standarisasi Nasional). (2010). SNI ISO 111932:2010 Sarung tangan untuk pemeriksaan medis sekali
pakai-Bagian 2: Spesifikasi untuk sarung tangan terbuat dari polivinil klorida (PVC). Jakarta, Indonesia: BSN.

Tanetrungroj, T., \& Prachayawarakorn, J. (2015). Effect of starch types on properties of biodegradable polymer based on thermoplastic starch process by injection molding technique. Songklanakarin Journal of Science and Technology, 37(2), 193-199.

Yamak, H. B. (2016). Thermal, mechanical and water resistance properties of LDPE/starch bio-based polymer blends for food packing applications. Journal of the Turkish Chemical Society Section A: Chemistry, 3(3), 637-656. https://doi. org/10.18596/jotcsa. 287300

Wan Noor, Z., Rahim, N. A. A., Osman, H., \& Ibrahim, M. (2014). Mechanical properties of starch filled polypropylene under exposure of hygrothermal conditions. The Malaysian Journal of Analytical Sciences, 18(2), 434-443.

Wang, G., Yang, X., \& Wang, W. (2019). Reinforcing linear lowdensity polyethylene with surfactant-treated microfibrillated cellulose. Polymers, 11(3), 441. https://doi.org/10.3390/ polym 11030441 
